\title{
10 Spatial differentiation of the economic development of Polish voivodeships and Ukrainian oblasts
}

\author{
Monika Bolińska and Olesia Chornenka
}

\subsection{Introduction}

Economic growth depends on many factors. One of them is the economic development of the regions. In turn, diversification of the economic development of regions may have a direct impact on the economic development of a country (Gurgul, Lach 2011).

A statistical and taxonomic analysis of the spatial diversity of economic development of the regions of Poland and Ukraine in 2004-2016 is the main goal of this chapter. Taxonomic indicators of economic development based on five macroeconomic variables were used in the study of oblasts and voivodeships: four stimulants (GDP per capita, investment rate, wages, net migration) and one deterrent (unemployment rate).

There are many studies dealing with the spatial differentiation of development of both the Polish and Ukrainian economies, on a local as well as on a regional level. But, comparative research on these two economies is extremely rare. To a large extent they concern relations between Polish and Ukrainian regions, which are directly adjacent to each other. It is worth mentioning Kowerski's work here (2017), which uses taxonomic indicators and econometric methods to study the socio-economic development of cross-border regions. In his considerations the author dealt with the Polish-Ukrainian borderlands. The conducted research shows that both taxonomy and econometric methods are a good tool for studying the socio-economic development of these economies, and the provinces and border regions of Poland and Ukraine (except the Lviv Oblast) are not the most developed in socio-economic terms in their respective countries (Kowerski 2017).

Among the works in this area, we can see those that show a positive impact on trade and investment between border regions. One such work is a study by Mikhel (2016), which researched the impact of Poland on the development of western Ukraine. These studies show significant links between Polish and Ukrainian entrepreneurs. Mikhel (2016) also points out that the share of exports of goods from regions such as Volyn, Lviv or Ternopil to Poland is increasing every year, which fortifies the development of trade relations between the economies in question. 
Based on the review of empirical research on the impact of immigrants on economic growth and development as well as the development of human capital, it may be concluded that immigrants exert a significant positive impact on these aspects in the host country. Koshulko and Koshulko (2016) were involved in research on the influence of the Ukrainian migration in Poland. In their research, they proved that most of the money earned by Ukrainians is spent mainly on living expenses in Poland, and only a small amount of the money earned in Poland is sent by wire transfer to Ukraine (Koshulko, Koshulko 2016).

The Polish and Ukrainian economies are compared not only because of their proximity to each other, nor solely due to their cultural similarity, but also because of the comparable level of GDP per capita in the 1990s. In Poland since the 1990s, an economic transformation has been taking place and since then the GDP per capita has been steadily rising, while Ukraine is still struggling with a low level of this value compared to Poland. Adarov et al. (2015) ascertain that Poland's success is not due to the change of the centrally planned economy to a free market economy that occurred in Poland at the turn of the 1980s and 1990s, but from a long-term systemic transformation process, whose echo was present until the first decade of the 20th century. In addition, the authors emphasize that the experience of the Polish economy cannot be directly implemented in the Ukrainian economy, but only part of the experience, especially that which is related to trade and openness of the economy (Adarov et al. 2015).

The chapter structure is as follows: Section 10.2 presents the methodology for constructing taxonomic indicators. Section 10.3 contains an analysis of the spatial differentiation of taxonomic indicators of the economic development of Polish voivodeships, while Section 10.4 presents the spatial differentiation of taxonomic indicators of the economic development of Ukraine's oblasts. Section 10.5 contains a comparative analysis of the spatial differentiation of the taxonomic indicators of the economic development of Polish voivodeships and Ukrainian oblasts. Chapter 10 closes with a summary and conclusions of the conducted considerations.

\subsection{Taxonomic methods employed}

The level of development of a voivodeship or an oblast can be characterized by many methods; one of them are taxonomic methods, which allow the classification of regions using metric measures. These measures transform the $n$-dimensional space of variables describing the level of development of the region into a one-dimensional real space. The need to use taxonomic measures is mainly due to the fact that there is no good order in $n$-dimensional spaces $(n \geq 2)$, so we are not able to compare any feature vectors.

Taxonomic methods have the form of a universal algorithm and are based on the following stages (for more on the stages of building development 
indicators see, e.g., in Willmott and Grimshaw 1969; Wishart 1969; Grabiński et al. 1989; Zeliaś 2000):

1 the selection of diagnostic variables describing the development of a given region (diagnostic variables);

2 the determination of the nature of variables in relation to the examined properties of the structure (a division into stimulants, destimulants and nominants);

3 selection of methods for estimating values of variables and units;

4 normalization of diagnostic variables aimed at freeing them from labels, so that they are mutually comparable;

5 determination of the synthetic variable value based on the chosen method of aggregation of diagnostic variables.

The selection of diagnostic variables was based on the availability of macroeconomic variables, which were listed on the Statistics Poland (GUS) ${ }^{1}$ and the State Statistics Service of Ukraine (ДССУ) ${ }^{2}$ websites.

Synthetic variables (first) allow for the ordering and comparison of units (voivodeships and oblasts) and (second) these variables also allow a classification of regions into groups with a similar degree of development. In this study, the authors based their research on synthetic variables, and grouped voivodeships and oblasts into quintile groups. The next quintiles contain regions with the highest, high, medium, low and the lowest level of economic development.

At the next stage, stimulants and destimulants of economic development should be distinguished from diagnostic variables. These concepts were introduced in Hellwig's work in 1968.

A stimulant of economic development is understood as being a variable whose high values are desirable from the point of view of the characteristics of the structure under study, while low values are undesirable. A destimulants, on the other hand, is such a macroeconomic variable whose high values cause an undesirable state of the studied structure, while an increase in the value of this variable deepens this state.

Among the macroeconomic variables discussed in previous chapters, the GDP per capita, investment rates, wages and migrations were accepted as stimulants of economic development, and the destimulants were the unemployment rates.

Destimulants can become stimulants and vice versa, which allows considering a set of diagnostic variables as a stimulant or deterrent syndrome. In the subsequent analyses, this destimulants is transformed into a stimulant based on the relationship:

$$
s_{j t}^{i}=\frac{1}{d_{j t}^{i}},
$$


where indexes $i=1,2, \ldots, 16(27), j=1,2, \ldots, 5)$ and $t=2004,2003, \ldots, 2016$ mean, respectively: voivodeships (oblasts), years and stimulants (s) (destimulants (d)) of economic development (see: Dykas 2009, 2017).

In the next step, the stimulants are standardized to unity, dividing the value of the $j$-th stimulant by its maximum value and thus excluding their labels:

$$
\bar{s}_{j t}^{i}=\frac{s_{j t}^{i}}{\max _{i t}\left(s_{j t}^{i}\right)},
$$

where $\bar{s}_{j t}^{i}$ means a standardized stimulant. The values $\bar{s}_{j t}^{i}$ are at the same time not greater than 1 and not less than 0 , which allows one to compare any standardized stimulant values.

In addition, the value of a stimulant equal to 1 is interpreted in such a way that in the $i$-th region in a given year $t$, the $j$-th stimulant assumed the maximum value in the group of regions studied. It also follows from this that the closer/further from 1 the value a standardized stimulant $\left(\bar{s}_{j t}^{i}\right)$ attains, in a given region, the more the region was characterized by a higher/lower degree of development in terms of the variable that the stimulant represents.

The study adopts a taxonomic method based on the highest value of the sum of Pearson's linear correlation coefficients between the taxonomic indicator $\left(S K_{t}^{i}\right)$, and standardized stimulants of economic development (see: Dykas et al. 2013 or Dykas 2017).

Let's suppose it's a $D=\left[d_{i j}\right]$ matrix of variables representing stimulants, where $d_{i j}$ is equal to the value of the $j$-th stimulant in region number $k$, where $i=k$ (modulo) 16 (27), therefore $i=k+p \cdot r(r=0$ for 2004, $r=1$ for 2005, .., $r=12$ for 2016 and $p=16(27))$.

Let $\mathrm{X}$ be a normalized matrix $\mathrm{D}$, where the normalization is accomplished utilizing the following transformation ${ }^{3}$ (see: Bolińska at al. 2018):

$$
X_{\bullet, j}=\frac{D_{\bullet}, j}{\max \left(D_{\bullet}\right)},
$$

when the $j$-column of the matrix $D$ is a stimulant, and:

$$
X_{\bullet, j}=1-\frac{D_{\bullet}, j}{\max \left(D_{\bullet, j}\right)},
$$

when the $j$-column of the matrix $D$ is a destimulant.

The taxonomic indicator $S K_{i}$ of the development of the $k$-th ( $i=k$ (modulo) 16 (27)) of the territorial unit is the following convex linear combination of normalized features:

$$
S K_{i}=\omega_{1} \cdot X_{i, 1}+\omega_{2} \cdot X_{i, 2}+\cdots+\omega_{5} \cdot X_{i, 5},
$$

where the value vector $\omega=\left(\omega_{1}, \omega_{2}, \ldots, \omega_{5}\right)$ is an argument for which the function: ${ }^{4}$ 


$$
F(\omega)=\sum_{j=1}^{5} \operatorname{cor}\left(X_{\bullet, j}, X^{*} \omega\right),
$$

takes the largest value.

We interpret the indicators $S K_{i}$ (for $i=1,2, \ldots, 16(27)$ ) in such a way that the closer (further) one they are, the better (worse) is the $i$-region. The value vector $\omega$ is determined based on distributed evolutionary algorithms. In addition, the individual coordinates $\omega_{i}(i=1,2,3, \ldots, 5)$ are as follows:

- in Poland: wages -0.260 , investment rates -0.252 , GDP per capita 0.199 , unemployment rates -0.189 , migrations -0.100 ,

- in Ukraine: wages -0.244 , investment rates -0.181 , GDP per capita 0.178 , unemployment rates -0.221 , migrations -0.176 ,

- jointly, both in Poland and in Ukraine: wages - 0.155, investment rates -0.240 , GDP per capita -0.168 , unemployment rates -0.230 , migrations -0.207 .

\subsection{Spatial differentiation of taxonomic indicators of economic development of voivodeships}

Map 10.1 presents the development of the taxonomic indicator in Polish voivodeships in the years 2004-2016. We can draw the following conclusions from this map:

- The highest level of economic development in the research period was characterized by those voivodeships with a high level of GDP per capita, high wages and low unemployment rates. These were the Mazowieckie (index value of 0.722), Pomorskie (0.550) and Wielkopolskie voivodeships (0.546).

- Voivodeships with high wages and a high level of GDP were in the group of voivodeships with a high level of economic development. This group includes the following voivodeships: Dolnośląskie (0.545), Małopolskie (0.532) and Śląskie (0.518).

- The group of voivodeships with an average value of the taxonomic index included the voivodeships of Lódzkie (0.495), Opolskie (0.475), Lubuskie (0.473) and Zachodniopomorskie (0.467).

- Low values of the taxonomic indicator were recorded in voivodeships in which low wages occurred during the research period. These were the Podlaskie (0.462), Podkarpackie (0.451) and Kujawsko-Pomorskie $(0.442)$ voivodeships.

- The group of voivodeships with the lowest value of the taxonomic index was composed of three voivodeships of eastern Poland: Świętokrzyskie (0.431), Warmińsko-Mazurskie (0.425) and Lubelskie (0.421). 


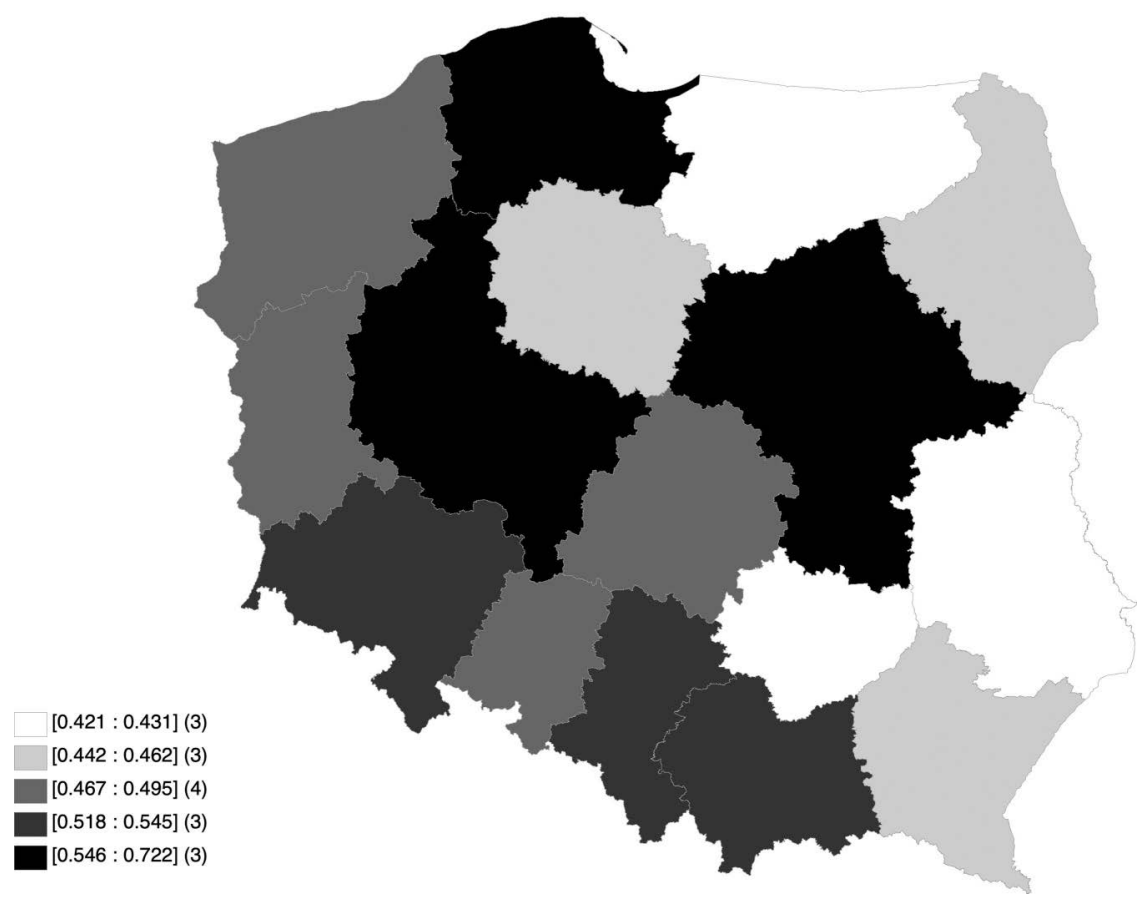

Map 10.1 Spatial differentiation of taxonomic indicators of economic development of voivodeships.

Source: Our own estimates based on: https://bdl.stat.gov.pl/BDL/start (access: 2019-12-30).

Table 10.1 summarizes the data on the development of taxonomic indicators in Polish voivodeships from specific years. This table also presents the coefficients of variation (understood as the relation of the standard deviation to the unconsidered average) of these indicators in the selected years and the correlation coefficients between the values of these indicators in subsequent years. The following conclusions can be drawn from the data contained in the table (see also Bolińska 2017):

- In all of the years singled out, the Mazowieckie Voivodeship had the highest value of the taxonomic indicator. In 2004, 2008 and 2016, the Wielkopolskie Voivodeship was in second place, while in 2013 the Dolnośląskie Voivodeship was in second place.

- The lowest value of this indicator in 2004 stood out in the Lubelskie and Warmińsko-Mazurskie voivodeships. The Warmińsko-Mazurskie Voivodeship also obtained the lowest value in 2008 and 2013. In addition, in 2013 the lowest value was also recorded in the Świętokrzyskie 
Table 10.1 Taxonomic indicators of economic development in voivodeships in selected years

\begin{tabular}{|c|c|c|c|c|}
\hline \multirow[t]{2}{*}{ Voivodeship } & \multicolumn{4}{|l|}{ Years } \\
\hline & 2004 & 2008 & 2013 & 2016 \\
\hline Dolnośląskie & 0.42 & 0.57 & 0.56 & 0.65 \\
\hline Kujawsko-Pomorskie & 0.35 & 0.48 & 0.43 & 0.47 \\
\hline Lubelskie & 0.33 & 0.45 & 0.44 & 0.45 \\
\hline Lubuskie & 0.37 & 0.47 & 0.46 & 0.54 \\
\hline Łódzkie & 0.38 & 0.54 & 0.51 & 0.55 \\
\hline Małopolskie & 0.43 & 0.57 & 0.52 & 0.61 \\
\hline Mazowieckie & 0.61 & 0.77 & 0.71 & 0.81 \\
\hline Opolskie & 0.36 & 0.48 & 0.47 & 0.63 \\
\hline Podkarpackie & 0.36 & 0.45 & 0.48 & 0.49 \\
\hline Podlaskie & 0.38 & 0.5 & 0.46 & 0.49 \\
\hline Pomorskie & 0.42 & 0.61 & 0.54 & 0.64 \\
\hline Śląskie & 0.4 & 0.58 & 0.51 & 0.6 \\
\hline Świętokrzyskie & 0.35 & 0.46 & 0.42 & 0.46 \\
\hline Warmińsko-Mazurskie & 0.33 & 0.44 & 0.42 & 0.47 \\
\hline Wielkopolskie & 0.45 & 0.61 & 0.52 & 0.66 \\
\hline Zachodniopomorskie & 0.38 & 0.51 & 0.50 & 0.51 \\
\hline Coefficients of variation & 0.170 & 0.163. & 0.143 & 0.175 \\
\hline \multirow[t]{3}{*}{ Correlation coefficients } & & Years & & \\
\hline & & $\begin{array}{c}2008 \text { and } \\
2004\end{array}$ & $\begin{array}{c}2013 \text { and } \\
2008\end{array}$ & $\begin{array}{c}2016 \text { and } \\
2013\end{array}$ \\
\hline & & 0.960 & 0.942 & 0.906 \\
\hline
\end{tabular}

Source: Our own estimates based on: https://bdl.stat.gov.pl/BDL/start (access: 2019-12-30).

Voivodeship. In 2016, the lowest value of this indicator was recorded in the Lubelskie Voivodeship.

- Between 2004 and 2008 (i.e., before the global financial crisis) an increase in the value of the taxonomic index was recorded in all Polish voivodeships, while the highest increase was noted in the Pomorskie, Śląskie and Łódzkie voivodeships. In these voivodeships, the increase was over $40 \%$.

- In the period between 2008 and 2013 (i.e., the period in which the effects of the global financial crisis were most noticeable) a decrease in the taxonomic indicator was noted in 15 out of 16 voivodeships. The only voivodeship in which instead of a decrease an increase was recorded was the Podkarpackie Voivodeship. The highest decrease in the taxonomic index (by over 10\%) was recorded in the following voivodeships: Pomorskie, Wielkopolskie, Śląskie and Kujawsko-Pomorskie.

- The decrease in taxonomic indicators of economic development in the aforementioned period of time resulted mainly from an increase in the unemployment rates. 
- In the last analyzed period of time (i.e., in the years 2013-2016), an increase in the taxonomic index was recorded in all voivodeships, with the highest increase recorded in Opolskie (by 34.3\%) and Wielkopolskie (26.7\%).

- Despite a decrease in the taxonomic indicator in earlier years, in the last of the years researched, the value of the discussed indicator was higher in all voivodeships, as compared to 2004. The most rapid increases in the indicator were recorded in the Opolskie (by 72.7\%) and Dolnośląskie $(55.3 \%)$ voivodeships.

- The conclusion of the coefficients of variation in Table 10.1 is that in the years 2004-2013 a process of convergence of taxonomic indicators of economic development took place, and after 2013 there was a clear divergence of these indicators. On the other hand, high correlation coefficients in subsequent years suggest a significant stability of spatial diversity of those voivodeships in undergoing economic development.

Figure 10.1 presents the trajectories of changes in economic development indicators in 2004-2016 in groups of Polish voivodeships and in the Polish economy as a whole. This figure shows the following:

- Over the entire research period, the value of the taxonomic indicator followed the same trend. In 2004, the lowest values of the taxonomic indicator in groups of voivodeships were recorded in the group of voivodeships of eastern Poland and they were 1.22 times lower than the values of these indicators for the group of voivodeships of central Poland.

- In the years 2004-2008, the average annual growth rate of the taxonomic index was $7.6 \%$. The highest average annual growth rate of the taxonomic indicator in 2004-2008 occurred in the group of voivodeships of central Poland (8.2\%), and the lowest in the group of voivodeships of eastern Poland (7.0\%).

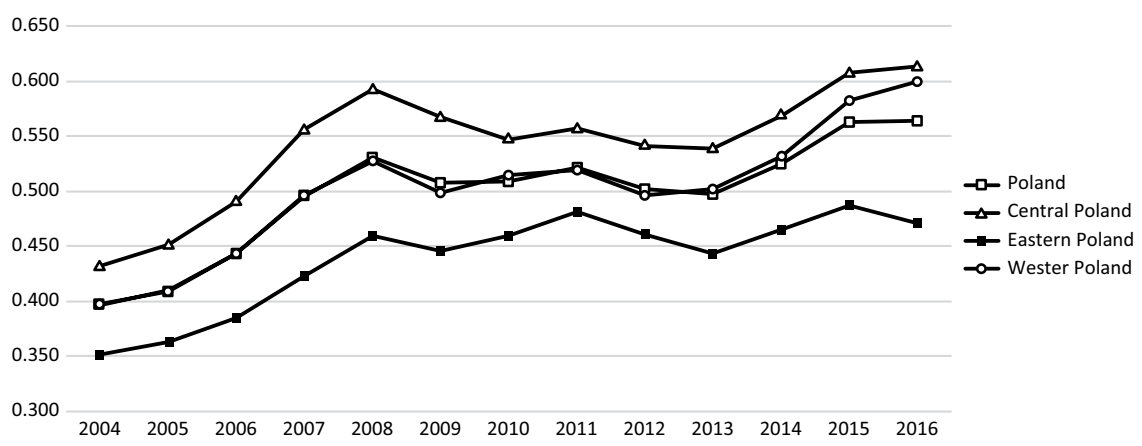

Figure 10.1 Taxonomic indicators of economic development in groups of voivodeships in 2004-2016.

Source: Our own estimates based on: https://bdl.stat.gov.pl/BDL/start (access: 2019-12-30). 
- Between 2006 and 2007, the largest increase in the taxonomic index was recorded throughout the entire period considered (13\%). This increase was recorded in the group of voivodeships of central Poland. The largest decrease of this indicator was recorded in the years 2008-2009 (5.5\%). The voivodeships of western Poland were characterized by this decrease.

- The years 2009-2013 manifest minor changes in the taxonomic indicator in the groups of Polish voivodeships. In central Poland, this ratio fell by $5.1 \%$, while in western Poland it increased by $0.7 \%$.

- The value of the taxonomic indicator in the years 2014-2016 increased in all the discussed groups, with the highest (annual average) growth recorded in western Poland (6.2\%), while the lowest growth rate occurred in eastern Poland $(0.6 \%)$.

- The average annual growth rate of the analyzed indicators over the years 2004-2016 for the entire Polish economy was 3\%, and was equal to the growth rate of this indicator in central Poland. In the same period, the growth rate in eastern Poland was $2.5 \%$, while in western it was $3.5 \%$. The taxonomic indicator in 2016 compared to 2004 in western Poland increased by over $50 \%$, while the lowest increase among all respondents was in the least-developed group of voivodeships, that is, in eastern Poland (34.1\%).

\subsection{Spatial differentiation of taxonomic indicators of economic development of oblasts}

In this part of the chapter, we will focus on the spatial differentiation of taxonomic indicators of economic development in the oblasts of Ukraine. Taxonomic indicators of economic development were based on the same macroeconomic variables as in the case of Poland.

The spatial differentiation of the values of taxonomic indicators of oblasts is shown on Map 10.2 and Table 10.2.

Map 10.2 indicates a significant spatial diversity of taxonomic indicators of economic development of the oblasts.

One may perceive a decidedly weaker economic development of western Ukraine, compared to the rest of the country. What's more, the oblasts in Left-bank Ukraine were characterized by a higher level of economic development compared to those on the right side of the Dnieper river (see also Tokarski, Chugaievska 2018 or Tokarski at al. 2019). ${ }^{5}$

Throughout the research period, the cities with a special status, that is, Kyiv (0.712) and Sevastopol (0.407), the Autonomous Republic of Crimea (0.397) and the oblasts of Kyiv (0.443), Odesa (0.384), Dnipropetrovsk (0.377), Kharkiv (0.359), Poltava (0.333), Donetsk (0.332) and Zaporizhzhya (0.331), were characterized by the highest taxonomic economic development rate of this indicator. In turn, the least developed in relation to this indicator were the following oblasts: Rivne (0.273), Kirovohrad (0.268), Sumy (0.267), Chernivtsi (0.256), Kherson (0.254), Zhytomyr (0.249) and Ternopil (0.247). 
Table 10.2 Taxonomic indicators of economic development in oblasts in selected years

\begin{tabular}{|c|c|c|c|c|}
\hline \multirow[t]{2}{*}{ Oblast } & \multicolumn{4}{|c|}{ Years } \\
\hline & 2004 & 2008 & 2013 & 2016 \\
\hline Autonomous Republic of Crimea & 0.33 & 0.43 & 0.42 & - \\
\hline Kharkiv & 0.36 & 0.41 & 0.35 & 0.32 \\
\hline Kherson & 0.21 & 0.32 & 0.25 & 0.23 \\
\hline Khmelnytskiy & 0.25 & 0.34 & 0.28 & 0.27 \\
\hline Cherkasy & 0.30 & 0.34 & 0.27 & 0.24 \\
\hline Chernihiv & 0.24 & 0.31 & 0.26 & 0.24 \\
\hline Chernivtsi & 0.23 & 0.38 & 0.30 & 0.24 \\
\hline Dnipropetrovsk & 0.37 & 0.42 & 0.37 & 0.32 \\
\hline Donetsk & 0.33 & 0.41 & 0.36 & 0.24 \\
\hline Ivano-Frankivsk & 0.27 & 0.37 & 0.31 & 0.28 \\
\hline Kyiv & 0.34 & 0.50 & 0.50 & 0.47 \\
\hline Kirovohrad & 0.24 & 0.29 & 0.28 & 0.25 \\
\hline Luhansk & 0.27 & 0.35 & 0.36 & 0.21 \\
\hline Lviv & 0.28 & 0.36 & 0.32 & 0.34 \\
\hline Mykolayiv & 0.29 & 0.33 & 0.33 & 0.29 \\
\hline Odesa & 0.36 & 0.45 & 0.39 & 0.34 \\
\hline Poltava & 0.32 & 0.40 & 0.34 & 0.29 \\
\hline Rivne & 0.30 & 0.32 & 0.28 & 0.25 \\
\hline Sumy & 0.23 & 0.31 & 0.28 & 0.27 \\
\hline Ternopil & 0.20 & 0.30 & 0.26 & 0.23 \\
\hline Vinnytsya & 0.23 & 0.33 & 0.30 & 0.25 \\
\hline Volyn & 0.24 & 0.33 & 0.30 & 0.25 \\
\hline Zakarpattia & 0.27 & 0.34 & 0.27 & 0.25 \\
\hline Zaporizhzhya & 0.32 & 0.38 & 0.33 & 0.28 \\
\hline Zhytomyr & 0.20 & 0.30 & 0.26 & 0.24 \\
\hline Kyiv & 0.72 & 0.87 & 0.71 & 0.64 \\
\hline Sevastopol & 0.36 & 0.47 & 0.41 & - \\
\hline Coefficients of variation & 0.334 & 0.291 & 0.280 & 0.314 \\
\hline Correlation coefficients & & $\begin{array}{l}\text { Years } \\
2008 \text { and 2004; } \\
0.958\end{array}$ & $\begin{array}{l}2013 \text { and 2008; } \\
0.968\end{array}$ & $\begin{array}{l}2016 \text { and } 2013 \\
0.939\end{array}$ \\
\hline
\end{tabular}

Source: Our own estimates based on: http://www.ukrstat.gov.ua/ (access: 2019-12-30).

Table 10.2 presents the taxonomic indicators of economic development in oblasts in selected years. The selection of those years was conditioned by the political and economic crises in Ukraine. These crises had a significant impact on the economic development of the oblasts; therefore, the following years were chosen for a detailed analysis of the taxonomic indicators of the economic development of the Ukrainian oblasts: 2004 (the Orange Revolution, November-December 2004), 2008 (the global financial crisis and gas conflict with Russia 2008-2009), 2013 (the Euro-Maidan and annexation of the Crimean peninsula and military conflict with the Russian Federation) and at the end of 2016, as a year of some stabilization of the economic 


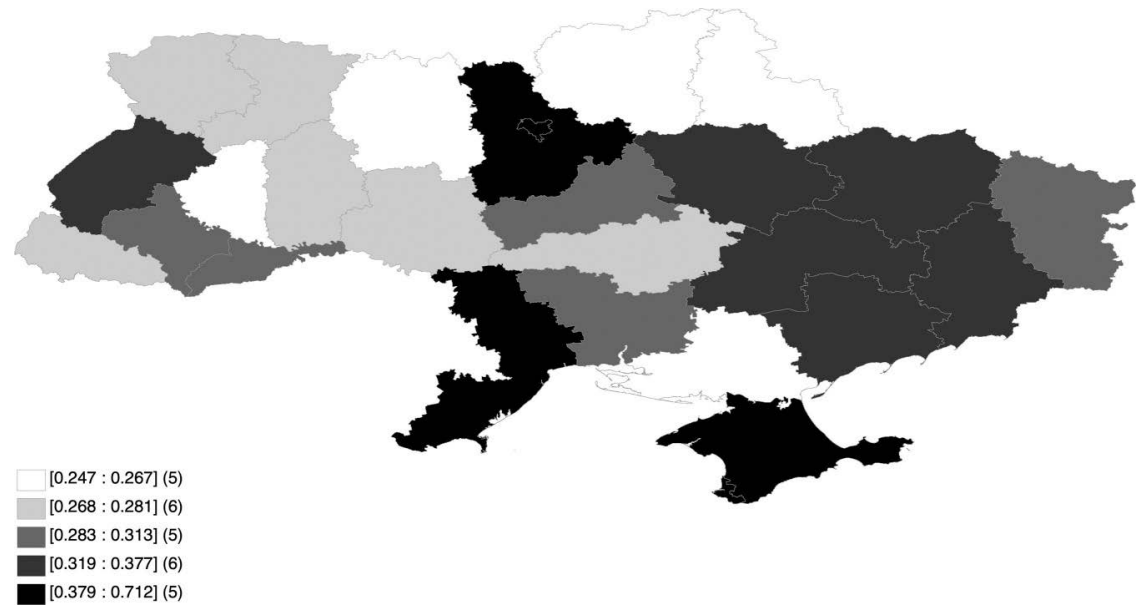

Map 10.2 Spatial differentiation of the taxonomic indicators of economic development of oblasts.

Source: Our own estimates based on: http://www.ukrstat.gov.ua/ (access: 2019-12-30).

situation in Ukraine after the economic crisis caused by the military conflict with Russia.

The year 2004 was the beginning of a period of development for the Ukrainian economy. The Orange Revolution that took place in 2004 led to a change in the political scene of Ukraine, and the election of Viktor Yushchenko as President of Ukraine (Golovko 2010). Analyzing the taxonomic indicator of the economic development of Ukrainian oblasts in 2004, we can see that by far the most developed oblasts were those of Dnipropetrovsk, Kharkiv, Odesa, the city of Sevastopol and Kyiv, all of which had the highest level of this indicator. In turn, the lowest level of the taxonomic indicator of economic development of the Ukrainian oblasts was recorded in the following regions: Zhytomyr, Ternopil, Kherson, Vinnytsya and Sumy.

The policy of President Viktor Yushchenko had a positive impact on the economy of Ukraine. Generally, in 2004-2008 (i.e., during the Yushchenko presidency) the economic growth fluctuated around $7 \%$, measured by the taxonomic development index. The year 2008 was difficult for the economic situation in Ukraine, because in addition to the global financial crisis (which significantly affected the Ukrainian economy), there was also a political conflict with the Russian Federation related to the signing of an agreement between Ukraine and Russia, concerning the supply of Russian gas to Ukraine. The main problems that occurred at the time of the signing of this agreement were the conditions for supplying natural gas, in particular the price of the gas (Rosenberger 2012). 
In 2008, the most developed with respect to the taxonomic index were the following oblasts: the City of Kyiv together with the oblast of Kyiv, Sevastopol along with the Autonomous Republic of Crimea and the Odesa Oblast. The least developed were the Kirovohrad, Zhytomyr, Ternopil, Sumy and Chernihiv oblasts.

The period 2013-2014 was the most problematic period in Ukrainian politics and the economy, after the economic crisis of the 1990s. Following the Euro-Maidan (November 2013-February 2014), Ukraine was faced with another conflict, this time of a military nature. The struggle began with the annexation of the Crimean Peninsula (March 2014), after which military operations have continued from April 2014, until the present. This time, the conflict afflicted the two most industrially developed oblasts of eastern Ukraine, namely the Donetsk and Luhansk oblasts (Klotz 2017). The Ukrainian economic situation, which was linked with politics, reacted to the above conflict with an economic crisis in the form of a decline in GDP and wages, as well as an increase in the unemployment rate. The crisis naturally contributed to a lowering of the taxonomic indicators of the economic development of the Ukrainian oblasts, in particular those directly affected by the war. The highest significance of this indicator in 2013 was recorded in the Kyiv, Odesa, and Dnipropetrovsk oblasts, the Autonomous Republic of Crimea and in the cities of Kyiv and Sevastopol. The lowest were recorded in the Zhytomyr, Ternopil, Chernihiv and Zakarpattia oblasts.

The year 2016 was distinguished by the fact that, for the first time after the economic crisis, an increase in the taxonomic indicators of economic development was recorded in most Ukrainian oblasts. During this period, the City of Kyiv and its oblast, together with the Lviv, and Kharkiv oblasts, stood out due to their significantly high taxonomic indicators. The Luhansk, Ternopil, Zhytomyr and Vinnytsya oblasts were distinguished by their low levels of taxonomic indicators.

Analyzing the coefficients of variation in Table 10.2, the following conclusions may be drawn: First, these coefficients are much higher in Ukraine than in Poland, which also means that the spatial diversity of the development of the Ukrainian economy is greater than that of Poland. Second, just like in Poland, the levels of these coefficients dropped until 2013, before rising significantly.

Considering the values of correlation coefficients between successive years, it turns out that the spatial diversity of the economic development of oblasts (like voivodeships) is stable over time.

The dynamics of taxonomic indicators of economic development in 20042008 once again indicate a high level of economic development over this time period. This period was characterized by an increase in taxonomic indicators in all oblasts, which proves that the economic policy at that time was rather effective. The average annual growth rate of these indicators fluctuated around $11 \%$ in the Chernivtsi, Ternopil, Kherson, Zhytomyr and 
Kyiv oblasts. An approximately 8\% increase was recorded in the Vinnytsya, Ivano-Frankivsk, Volyn, Khmelnytskiy and Luhansk oblasts. An increase of 3\% was recorded in the following oblasts: Mykolayiv, Dnipropetrovsk, Kharkiv, Cherkasy and Rivne.

After the gas conflict and the global financial crisis, the situation in the Ukrainian economy deteriorated significantly. In the period of 2009-2014, the taxonomic decline rate of economic development fluctuated around $3.5 \%$. It is worth noting that the decline was an element of the armed conflict with Russia. The most noticeable destabilization in the years 2009-2014 took place in the Donetsk, Chernivtsi, Luhansk, and Zakarpattia oblasts (the rate of decline in the taxonomic indicators of economic development in these oblasts fluctuated around 5\%). The least noticeable decline in these indicators occurred in the following oblasts: Mykolayiv, Ivano-Frankivsk, Kirovohrad and Dnipropetrovsk (a decrease of approx. $2 \%$ ).

After the most active phase of the military conflict in 2014, the economic situation in Ukraine stabilized somewhat in 2015-2016. Nevertheless, during this period, a decrease in the taxonomic index of economic development was rated at about $1.7 \%$ on a scale of the economy as a whole. It should be noted, however, that in Lviv, Donetsk, Sumy and Zhytomyr oblasts, an increase in the taxonomic indicator of economic development was perceived. At that time, the Ivano-Frankivsk, Dnipropetrovsk, Kharkiv, Zaporizhzhya and Vinnytsya oblasts still manifested an approximate 6\% drop in the above indicator. Comparing, in turn, the taxonomic indicators of the Ukrainian oblasts in 2004 and 2016, we can see that their values were very similar, which proves that after the political and economic crises, the indicators of the development of the Ukrainian economy returned to their 2004 levels.

As can be seen in Figure 10.2 during a period of economic growth in the Ukrainian economy (i.e., in 2004-2008), the trajectories of the taxonomic index of economic development of oblast groups were very similar to each other. An upward trend of this indicator in the aforementioned period is also noticeable. Then in 2009 the first crisis for the Ukrainian economy, associated with the global financial crisis and the gas conflict with Russia, appeared. Another critical moment shown on the figure is at the turn of 2013-2014, and was related to the military conflict in eastern Ukraine and the annexation of the Crimean Peninsula.

In the research period, the lowest level of taxonomic indicator of economic development was recorded in the group of western Ukrainian oblasts. ${ }^{6}$ Such a level of this indicator is conditioned by the low level of GDP per capita and wages, and the high unemployment in these regions. Generally, most of the oblasts in this group do not have a well-developed industrial and service sector. The basic types of economic activity in the western Ukrainian oblasts are agriculture, construction and tourist services. Despite the fact that this group of oblasts is the largest in terms of the number of oblasts it contains, in terms of economic development we can only distinguish the Lviv Oblast 


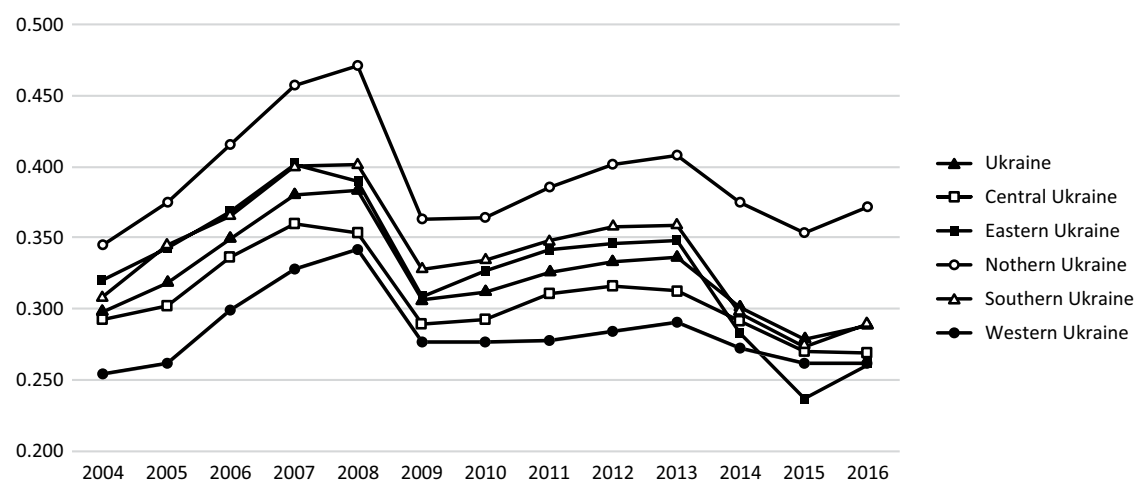

Figure 10.2 Taxonomic indicators of economic development in oblast groups in 2004-2016.

Source: Our own estimates based on: http://www.ukrstat.gov.ua/ (access: 2019-12-30).

together with the city of Lviv, which is the largest and most developed city in the western part of Ukraine, as making noteworthy economic progress.

By far the most developed oblast of central Ukraine was the Dnipropetrovsk Oblast together with the city of Dnipro, which is one of the most important financial and service centers of Ukraine. The high level of economic development of the Dnipropetrovsk Oblast has a significant impact on the level of economic development of the central Ukrainian oblast group. Among the less-developed oblasts of this group, we can distinguish Kirovohrad and Vinnytsya.

Northern Ukraine is the most developed part of the country. Despite the fact that three oblasts included in this group (Sumy, Chernihiv and Zhytomyr) in the research period were characterized by a rather low level of GDP per capita, and investment along with a rather high unemployment rate (which translated into a low level of economic development), the group had the highest level of the taxonomic indicator, mainly due to the capital City of Kyiv. Over $20 \%$ of the country's GDP is generated in Kyiv, which, combined with a highly centralized system, distinguishes this part of the country regarding economic growth; in addition, it exerts a significant impact on the spatial diversity of the economic development of the Ukrainian oblasts.

Southern Ukraine also had a fairly high level of taxonomic economic development in the period under review. This indicator was largely influenced by the very low level of unemployment in this part of the country, together with a high level of investment. Southern Ukraine having access to the Black and Azov Seas was also important in the framework of economic development, particularly with regard to the increase in tourism in this region, as well as the expansion of other commercial activities. 
Eastern Ukraine is the most economically advanced part of the country. Modern heavy industry together with access to a large amount of natural resources, especially energy (gas, oil and to a great extent, coal), has caused the group of oblasts of eastern Ukraine to be one of the most developed oblasts of the country, as evidenced by the high level of the taxonomic indicator of economic development over the years 2004-2016. Precisely because of this high level of economic development, and greater integration with Russia, the oblasts of the eastern Ukrainian group were affected by the military conflict in 2014, which not only resulted in a destabilization of the region, but was the root of the economic crisis that extended throughout the country.

Analyzing the pace of economic development throughout the country, an average annual decrease of taxonomic indicators of economic development in the years 2004-2016 was noted to be approximately $0.3 \%$. In turn, when broken down into groups of regions, we can see that the group of oblasts of western and northern Ukraine, in the analyzed period, manifested an increase in taxonomic indicators of $0.3 \%$ and $0.6 \%$. A slowdown in economic growth in the form of declines in taxonomic indicators was recorded in the eastern, southern and central parts of the country $(-1.7 \%,-0.6 \%,-0.7 \%$, respectively).

A significant acceleration of the pace of economic development was recorded in the period of 2004-2008 in all groups of oblasts; on average in Ukraine as a whole, there was about a $7 \%$ increase in taxonomic indicators during this period. The highest increase in these indicators was noted in the western Ukrainian oblast group (7.7\%), followed by the northern and southern parts of the country (7.1\% and $6.7 \%$, respectively). The weakest growth rate in the years 2004-2008 was recorded in the groups of regions of eastern $(5.0 \%)$ and central $(4.8 \%)$ Ukraine.

The period 2012-2015 was distinguished by a lackluster economic development rate throughout the country (approximately a 5.6\% average annual decrease in taxonomic indicators). During this period, taxonomic indicators dropped in all oblast groups. A decrease of 5\% was recorded in the western, northern and central Ukrainian oblast groups, while the highest decreases in these indicators were recorded in the eastern (11.8\%) and southern $(10.6 \%)$ parts of the country.

\subsection{Spatial differentiation of taxonomic indicators of economic development of Polish voivodeships and Ukrainian oblasts}

Map 10.3 presents the development of the taxonomic indicator of economic development jointly for the Polish and Ukrainian economies in 2004-2016. We can conclude from this map that (see also Bolińska, Gomółka 2018):

- Out of 43 analyzed regions, the most developed were regions in which high investments were recorded. These were the capital of Ukraine Kyiv (0.589) and the Mazowieckie Voivodeship (0.510). 

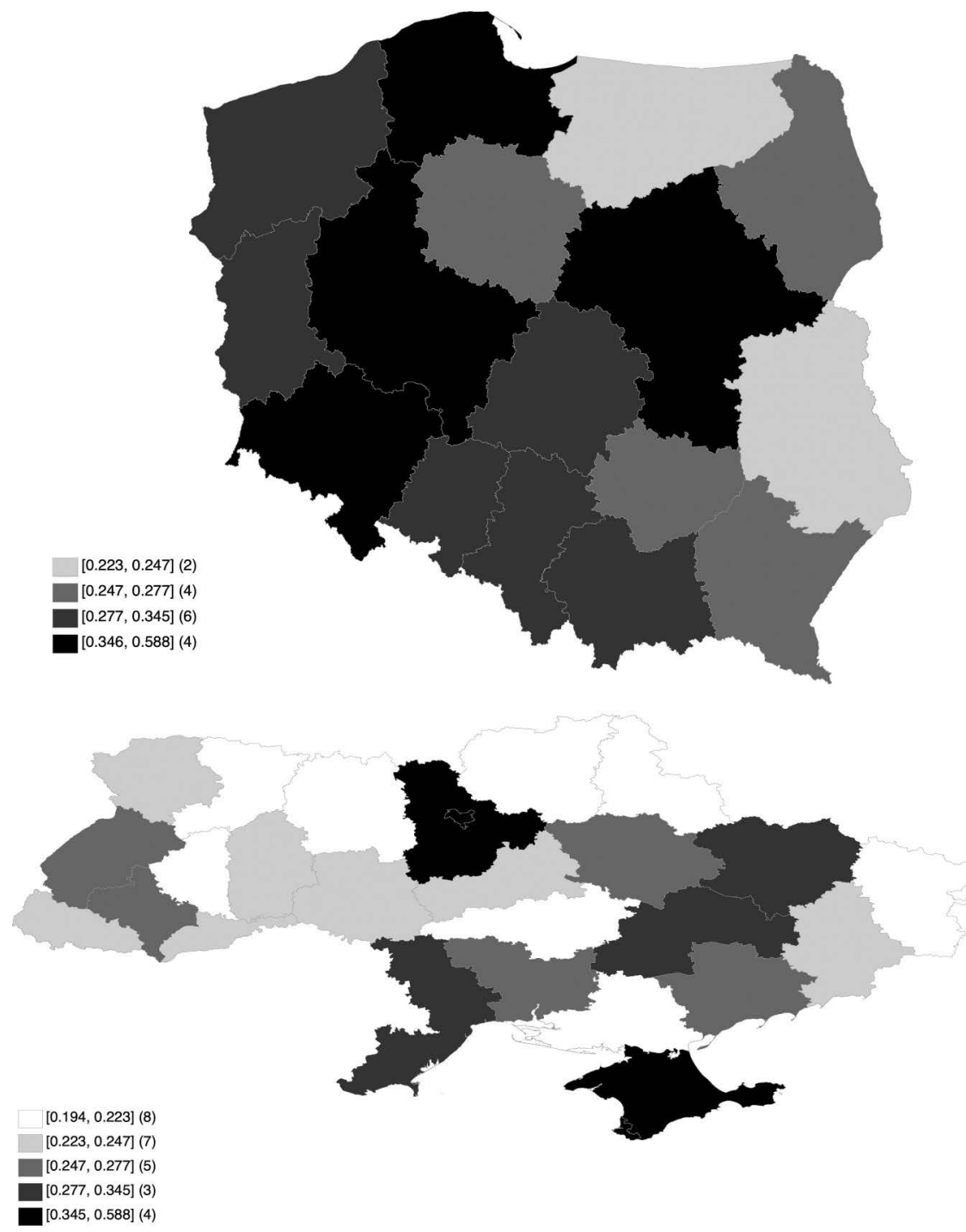

Map 10.3 Spatial differentiation of taxonomic indicators of economic development of voivodeships and oblasts.

In the case of the Autonomous Republic of Crimea and in 2004-2013.

The group of the most developed regions in the research period also included the Kyiv Oblast (0.389) as the natural economic base of the Kyiv metropolis, as well as the Wielkopolskie Voivodeship (0.357), the Autonomous Republic of Crimea (0.355), the voivodeships of Pomorskie (0.351), and Dolnośląskie $(0.347)$ and the city with a special status, Sevastopol (0.347). 
- The group of regions with a high value of this analyzed indicator was made up of three oblasts, Odesa (0.321), Kharkiv (0.296) and Dnipropetrovsk (0.292), and six voivodeships, the Małopolskie (0.346), Śląskie (0.320), Łódzkie (0.302), Opolskie (0.292), Lubuskie (0.289) and Zachodniopomorskie (0.284).

- The group of underdeveloped regions was made up of two voivodeships of eastern Poland and seven oblasts in Ukraine. This group included the Warmińsko-Mazurskie Voivodeship (0.247), Chernivtsi Oblast (0.245), Lubelskie Voivodeship (0.244) and the following oblasts: (0.237), Volyn (0.234), Cherkasy (0.229), Khmelnytskiy (0.228), Zakarpattia (0.225) and Vinnytsya (0.223).

- The group with the lowest values of the taxonomic indexes was composed of only Ukrainian oblasts. This group was made up of the following oblasts: Luhansk (0.222), Rivne (0.215), Kirovohrad (0.214), Sumy (0.206), Ternopil (0.203), Kherson (0.201), Chernivtsi (0.201) and Zhytomyr (0.194).

Table 10.3 summarizes the data on the value of the analyzed variable in all voivodeships and oblasts in the years selected as before. From the data summarized in this table, the following is evident:

- In 2004, 2008 and 2013, the highest value among all the discussed regions was in Kyiv, while in 2016 the Ukrainian capital was overtaken by the Mazowieckie Voivodeship (previously occupying second place in this ranking).

- The lowest values in all the years discussed were in the Ukrainian oblasts. In 2004, it was the Zhytomyr Oblast, in 2008 the Kirovohrad Oblast, in 2013 the Kherson Oblast, and in the last analyzed year 2016 the Luhansk Oblast.

- Between 2004 and 2008, in most of the regions analyzed (except for the Rivne and Chernivtsi oblasts in which this value remained unchanged), the level of the taxonomic index increased, while the highest increase, by $78.4 \%$, was recorded in the Chernivtsi region. Another circuit with a high increase in this indicator was the region of Kherson (an increase of $60.2 \%$ ). In Polish voivodeships, this increase was lower, with the Śląskie $(13 \%)$ and Wielkopolskie (12.2\%) voivodeships standing out.

- The period between 2008 and 2013 resulted in a decrease in the value of the taxonomic indicator. The effects of the global financial crisis and the gas conflict between Ukraine and Russia were most felt in the oblast, in which this indicator fell by almost $34 \%$, that is, the Kherson Oblast, which in the previous period recorded the largest increase in the taxonomic rate of economic development between 2008 and 2013, was among those regions with the most significant decrease (32.5\%). During the aforementioned period of time, in the Podkarpackie Voivodeship, a slight $(4.1 \%)$ increase of the analyzed indicator was recorded, while in the Dolnośląskie Voivodeship, no change was perceived. 
Table 10.3 Taxonomic indicators in Polish voivodeships and Ukrainian oblasts in selected years

\begin{tabular}{|c|c|c|c|c|c|}
\hline \multirow[t]{2}{*}{ Voivodeship or oblast } & \multicolumn{4}{|l|}{ Years } & \multirow{2}{*}{$\begin{array}{l}\text { Year 2016, (year } \\
2004=100 \text { ) }\end{array}$} \\
\hline & 2004 & 2008 & 2013 & 2016 & \\
\hline Dolnośląskie & 0.25 & 0.36 & 0.36 & 0.43 & 171.51 \\
\hline Kujawsko-Pomorskie & 0.21 & 0.29 & 0.26 & 0.3 & 140.49 \\
\hline Lubelskie & 0.19 & 0.26 & 0.26 & 0.28 & 147.94 \\
\hline Lubuskie & 0.22 & 0.29 & 0.28 & 0.34 & 153.91 \\
\hline Łódzkie & 0.23 & 0.33 & 0.31 & 0.35 & 152.88 \\
\hline Małopolskie & 0.28 & 0.37 & 0.34 & 0.41 & 147.82 \\
\hline Mazowieckie & 0.43 & 0.53 & 0.51 & 0.57 & 132.85 \\
\hline Opolskie & 0.22 & 0.3 & 0.29 & 0.38 & 170.37 \\
\hline Podkarpackie & 0.21 & 0.27 & 0.28 & 0.3 & 140.42 \\
\hline Podlaskie & 0.23 & 0.3 & 0.27 & 0.3 & 135.21 \\
\hline Pomorskie & 0.27 & 0.38 & 0.35 & 0.43 & 159.9 \\
\hline Śląskie & 0.24 & 0.36 & 0.32 & 0.38 & 159.87 \\
\hline Świętokrzyskie & 0.21 & 0.28 & 0.25 & 0.29 & 138.00 \\
\hline Warmińsko-Mazurskie & 0.2 & 0.26 & 0.24 & 0.28 & 145.54 \\
\hline Wielkopolskie & 0.29 & 0.39 & 0.35 & 0.45 & 155.00 \\
\hline Zachodniopomorskie & 0.23 & 0.31 & 0.3 & 0.32 & 142.88 \\
\hline Autonomous Republic of Crimea & 0.3 & 0.39 & 0.37 & - & $122.85^{\mathrm{a}}$ \\
\hline Vinnytsya & 0.2 & 0.28 & 0.23 & 0.18 & 92.39 \\
\hline Volyn & 0.22 & 0.29 & 0.24 & 0.2 & 93.51 \\
\hline Dnipropetrovsk & 0.31 & 0.33 & 0.27 & 0.24 & 76.33 \\
\hline Donetsk & 0.26 & 0.32 & 0.25 & 0.14 & 55.91 \\
\hline Zhytomyr & 0.16 & 0.25 & 0.19 & 0.18 & 112.62 \\
\hline Zakarpattia & 0.23 & 0.29 & 0.21 & 0.19 & 82.86 \\
\hline Zaporizhzhya & 0.26 & 0.3 & 0.25 & 0.2 & 77.54 \\
\hline Ivano-Frankivsk & 0.23 & 0.32 & 0.25 & 0.22 & 96.91 \\
\hline Kyiv & 0.31 & 0.46 & 0.43 & 0.41 & 134.33 \\
\hline Kirovohrad & 0.2 & 0.24 & 0.21 & 0.19 & 95.98 \\
\hline Luhansk & 0.21 & 0.28 & 0.27 & 0.14 & 67.72 \\
\hline Lviv & 0.25 & 0.31 & 0.25 & 0.28 & 113.5 \\
\hline Mykolayiv & 0.24 & 0.27 & 0.25 & 0.23 & 92.32 \\
\hline Odesa & 0.32 & 0.4 & 0.32 & 0.28 & 85.83 \\
\hline Poltava & 0.27 & 0.33 & 0.26 & 0.22 & 79.16 \\
\hline Rivne & 0.27 & 0.27 & 0.2 & 0.18 & 66.67 \\
\hline Sumy & 0.19 & 0.25 & 0.21 & 0.21 & 113.21 \\
\hline Ternopil & 0.17 & 0.26 & 0.21 & 0.18 & 108.37 \\
\hline Kharkiv & 0.33 & 0.34 & 0.26 & 0.25 & 76.14 \\
\hline Kherson & 0.17 & 0.28 & 0.18 & 0.18 & 101.4 \\
\hline Khmelnytskiy & 0.23 & 0.3 & 0.22 & 0.22 & 93.71 \\
\hline Cherkasy & 0.29 & 0.29 & 0.2 & 0.18 & 61.94 \\
\hline Chernivtsi & 0.2 & 0.36 & 0.24 & 0.19 & 95.48 \\
\hline Chernihiv & 0.2 & 0.26 & 0.19 & 0.18 & 91.68 \\
\hline Kyiv & 0.64 & 0.73 & 0.56 & 0.5 & 78.51 \\
\hline Sevastopol & 0.31 & 0.42 & 0.34 & - & $108.73^{\mathrm{a}}$ \\
\hline
\end{tabular}

Source: Our own estimates based on: http://www.ukrstat.gov.ua/ and https://bdl.stat.gov.pl/ BDL/start (access: 2019-12-30).

a In 2013. 
- As a result of the Euro-Maidan, there was a decrease in the value of the taxonomic indicator of economic development in 2013-2016 in most oblasts (the Khmelnytskiy region was the only one in which no change was recorded at that time). The highest decrease was recorded in the Donbas (Luhansk Oblast, a 47.2\% decrease and in the Donetsk Oblast, a decrease of $42.8 \%)$.

- In 2013-2016, all voivodeships were characterized by an increase in this analyzed indicator. The highest increase of the indicator discussed here in the research period was recorded in the Opolskie (32.5\%) and Wielkopolskie (29\%) voivodeships.

Figure 10.3 presents the trajectories of the taxonomic indicator of economic development in groups of voivodeships, in the Polish economy as a whole, as well as in groups of oblasts and the entire Ukrainian economy in the years 2004-2016. We can draw the following conclusions from this map:

- The highest level of economic development in the first year of the analyses was recorded in the group of northern Ukrainian oblasts. The taxonomic index in the said group was 1.5 times higher than the least developed group of voivodeships in eastern Poland, at that time.

- Until 2007, all groups discussed had the same tendency to change. In 2004-2007, the highest average annual growth of the analyzed indicator was recorded in the group of oblasts of southern Ukraine, and

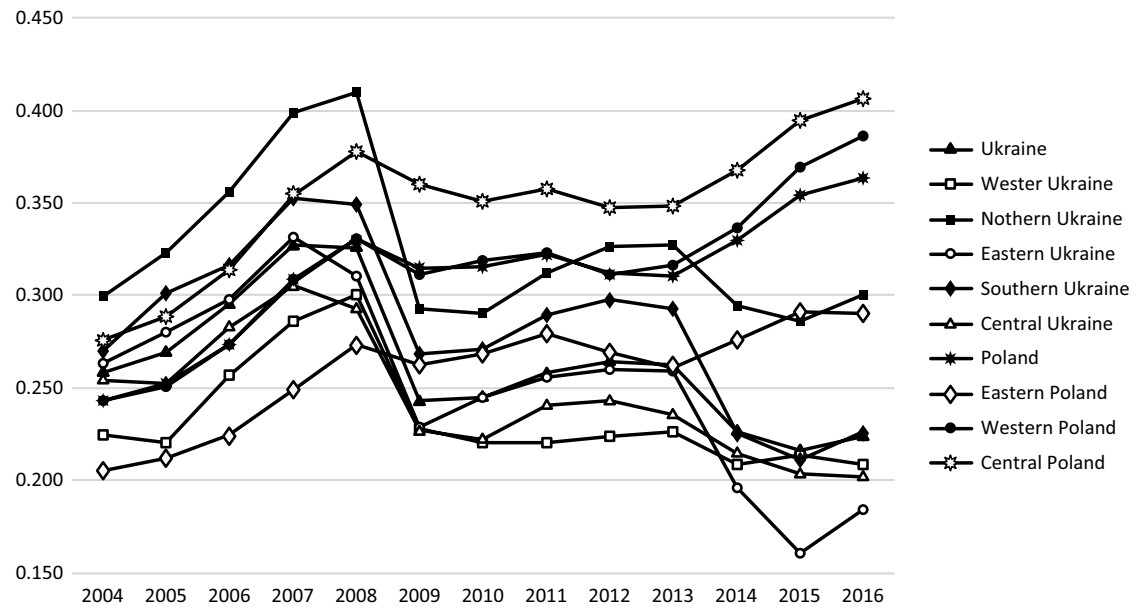

Figure 10.3 Taxonomic indicators of economic development in groups of voivodeships and groups of oblasts in 2004-2016.

Source: Our own estimates based on: http://www.ukrstat.gov.ua/ and https://bdl.stat.gov.pl/ BDL/start (access: 2019-12-30). 
was at a level of $9.3 \%$. The group of oblasts of northern Ukraine $(8.8 \%)$ and the group of voivodeships of central Poland (8.7\%) also had a high growth rate.

- The effect of the global financial crisis and the Russian-Ukrainian gas conflict was a decrease in economic development in 2009 in all the regions discussed. In Poland, the value of the taxonomic index decreased by about $5 \%$, while in Ukraine this decrease was already over $25 \%$.

- The years 2009-2014 increased the rate of economic development in Poland by $1.0 \%$ and in all voivodeship groups. In the same period, Ukraine saw a decline in economic development at a rate of $1.5 \%$. The only group of Ukrainian oblasts in which the value of the analyzed taxonomic index (equal to $1.5 \%$ ) increased in the discussed period of time was the group of oblasts of northern Ukraine.

- In the entire analyzed period, the taxonomic index for the Polish economy increased by $49.3 \%$; the largest increase among voivodeship groups was recorded in western Poland (an increase of 58.8\%). On the other hand, in the Ukrainian economy in the discussed period, a decrease in the taxonomic index of $13.5 \%$ was noted, with the highest decrease recorded in the group of eastern Ukrainian oblasts (by as much as $30.2 \%$ ), while the lowest decrease occurred in the northern Ukrainian oblasts $(0.2 \%)$.

- The group of central Poland voivodeships had the highest value of the taxonomic index in 2016; this value was over 2.2 times higher than the value of the taxonomic index of the group of oblasts from eastern Ukraine, the country's group of oblasts with the lowest economic progress, for this year. The value of the taxonomic index in Poland in the last year subjected to our research (2016) was over 1.6 times higher than in Ukraine.

Figure 10.4 shows the trajectories of the taxonomic indicator of economic development in the Mazowieckie Voivodeship, Kyiv Oblast and the City of Kyiv, as well as in the Polish and Ukrainian economies as a whole. We can draw the following conclusions from this map:

- In the first year of our analyses, in the City of Kyiv and in the Kyiv Oblast, the taxonomic index was 1.2 times higher than in the Mazowieckie Voivodeship. In addition, this indicator in the Ukrainian economy (equal to 0.26 ) was higher than in the Polish economy (equal to 0.24).

- From the first year of observation to 2008, the average annual growth rate of the taxonomic index in the City of Kyiv and the Kyiv Oblast (5.5\%) and the Mazowieckie Voivodeship (5.3\%) was at a similar level. However, for the Polish economy as a whole, this growth was $7.9 \%$, and in Ukraine it was slightly lower and amounted to $6 \%$.

- During the years 2008-2009 in the City of Kyiv and the Kyiv Oblast the taxonomic index fell by almost 34\%, while in the Mazowieckie Voivodeship this decrease was much smaller and amounted to less than $4 \%$. 


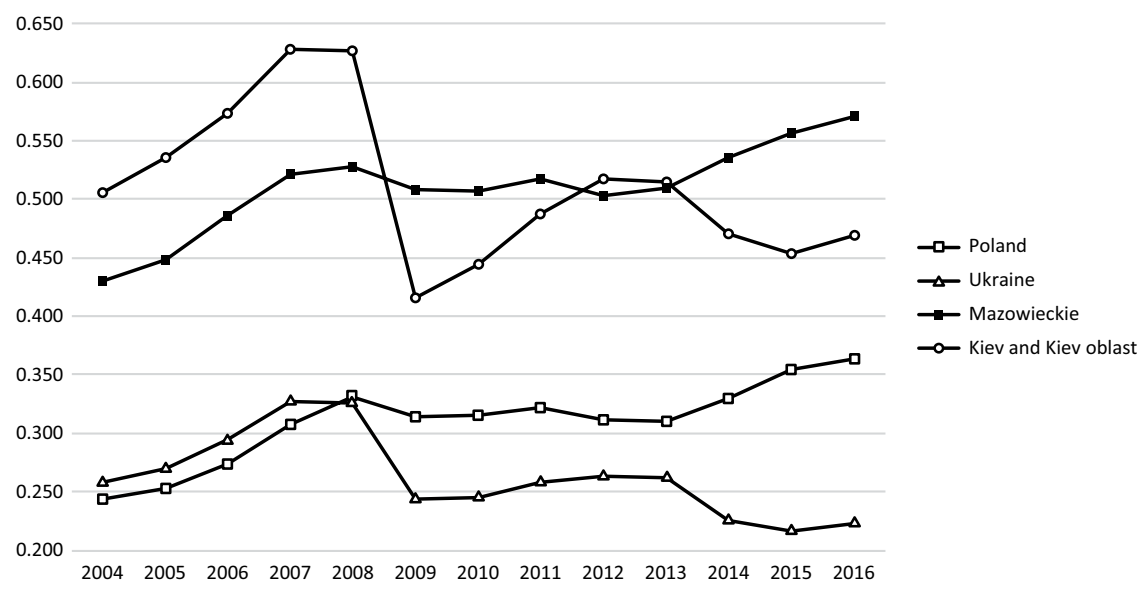

Figure 10.4 Taxonomic indicators of economic development in the Mazowieckie Voivodeship, Kyiv and the Kyiv Oblast, as well as in Poland in the years 2004-2016.

Source: Our own estimates based on: http://www.ukrstat.gov.ua/ and https://bdl.stat.gov.pl/ BDL/start (access: 2019-12-30).

- In the years 2009-2013, the value of the taxonomic index increased on average by about $0.1 \%$ in the Mazowieckie Voivodeship. This increase in the City of Kyiv and the Kyiv Oblast was much higher and amounted to $5.5 \%$. In Poland, this ratio between the discussed years did not fluctuate significantly (an average annual decrease of $0.3 \%$ ), but in Ukraine the value of the discussed index increased by almost $2 \%$ on average, annually.

- The last years of observation (2014/2016) manifested a decrease in the average annual growth rate both in Ukraine (by $0.6 \%$ ) as well as in Kyiv and the Kyiv Oblast (by $0.2 \%$ ) and an increase of this indicator in Poland (by 5.0\%) and the Mazowieckie Voivodeship (by 3.3\%).

- Over the entire research period, the value of the taxonomic indicator increased in the Mazowieckie Voivodeship by almost 33\%, while in the City of Kyiv together with the Kyiv Oblast, the value of this indicator decreased by $13.5 \%$.

\subsection{Summary}

The considerations this chapter can be summarized as follows:

i The economic development of the Polish and Ukrainian economies is heavily dependent on socio-political stability. In the analyzed period, fluctuations in the value of the taxonomic index of the economic development of oblasts and voivodeships were associated with the global financial crisis and socio-political destabilization in Ukraine. 
ii The best-developed Polish Voivodeship was the Mazowieckie Voivodeship, whereas the least-developed voivodeships were the three voivodeships of eastern Poland: the Świętokrzyskie, Warmińsko-Mazurskie and Lubelskie.

iii During the research period (i.e., in the years 2004-2016), the value of the taxonomic indicator fluctuated significantly in all Polish voivodeships, despite a decrease in the value of the taxonomic indicator after the global financial crisis (in the years 2009-2013). In the last analyzed year, an increase in economic development was recorded in all the voivodeships, with the highest increase being noted in the Opolskie and Dolnośląskie voivodeships.

iv In the discussed period, the most developed group of voivodeships was that of central Poland, whereas the lowest value of the taxonomic indicator throughout the entire research period was characteristic for eastern Poland.

$\mathrm{V}$ Decreases in the GDP per capita, wages and investment rates together with an increase in unemployment rates naturally contributed to the shaping of the taxonomic indicators of economic development of the oblasts. In the period under consideration, the cities of Kyiv and Sevastopol, the Autonomous Republic of Crimea and the oblasts of Kyiv, Odesa, Dnipropetrovsk, Kharkiv, Poltava, and Zaporizhzhya were characterized by a high level of taxonomic indicators. This was in contrast to the less-developed oblasts, according to the taxonomic indexes of Rivne, Kirovohrad, Chernihiv, Kherson, Zhytomyr and Ternopil.

vi This diversification of economic development is characteristic of the Ukrainian oblasts. In the years 2004-2016, significant differences were recorded in the shaping of taxonomic indicators of economic development among Ukrainian oblasts. The western part of the country is definitely the least developed, while the groups of central and eastern Ukrainian oblasts are among those with high economic growth; the northern and southern parts of the country in the research period were characterized by the highest level of taxonomic indicators of economic expansion ( 0.387 on average within the group during the research period). Moreover, the City of Kyiv (together with the Kyiv Oblast) attained the highest value of this indicator. To a large extent, the level of economic development of the capital (Kyiv) was affected by the highest level of GDP per capita, and wages and investment, combined with low unemployment, as well as the highly centralized system of the Ukrainian state. The regional economic policy of Ukraine, however, demands immediate change; it is necessary to emphasize a reduction of the differentiation of economic growth in the oblasts, as well as a change in the approach to state management from centralization to decentralization, which is important from the perspective of equalizing differences in economic expansion. 
vii The most developed regions of all those discussed in this chapter were those of the capital of Ukraine, Kyiv, and the Mazowieckie Voivodeship. The next places were occupied by the Kyiv Oblast and the Polish voivodeship with the lowest level of unemployment - Wielkopolskie. The lowest level of economic growth among all the regions discussed was found in two oblasts of northern Ukraine, the Chernihiv and Zhytomyr oblasts.

viii Between 2004 and 2016, two voivodeships of western Poland (Dolnośląskie and Opolskie) recorded the largest increase in the taxonomic index. However, the highest decrease in economic expansion in the analyzed period was recorded in the Donetsk (eastern Ukraine) and Cherkasy (central Ukraine) oblasts.

ix Despite the fact that in the initial period of this analysis, the group of northern Ukrainian oblasts was achieving the most economic progress, in the final period, this group was overtaken by both the voivodeships of western and central Poland; only the group of voivodeships of eastern Poland (which in the first year of this analysis was the least developed) in 2016 was manifesting less growth than northern Ukraine. The remaining groups of oblasts in the last year of the analysis (2016) were making less progress than the least-developed group of Polish voivodeships.

$x$ Comparing the best developed voivodeship of Poland and Kyiv, together with the Kyiv Oblast, we can state that in the first year of the research, the analyzed region of Ukraine, that is, Kyiv, was economically advancing at a faster rate. As a result of the Euro-Maidan and the Russian-Ukrainian gas conflict in 2016, the level of the taxonomic index of the Mazowieckie Voivodeship was 1.2 times higher than in the City of Kyiv and the Kyiv Oblast.

\section{Notes}

1 https://bdl.stat.gov.pl/BDL/start (access: 2019-12-30).

2 http://www.UKRSTAT.gov.ua/ (access: 2019-12-30).

3 For a matrix $M=\left[m_{i j}\right]$, the notation $M_{\bullet, j}$ means the j column of this matrix.

4 For $M=\left[m_{i j}\right]$ and $N=\left[n_{i j}\right]$ symbol $M * N$ signify the multiplication of the matrices.

5 Kyiv, which lies on both sides of the Dnieper, is an exception, as it attained the highest level of economic development.

6 An exception was the year of 2015, when the lowest level of this indicator was recorded in the group of oblasts of eastern. 